\title{
Production and quality of Sweet Grape tomato in response to foliar fertilization with boron
}

\author{
Raphael O Melo $^{1 \mathbb{D}}$; Hermínia P Martinez ${ }^{1 \mathbb{D}}$; Antonio PS Carneiro1 ${ }^{\mathbb{D}}$ \\ ${ }^{1}$ Universidade Federal de Viçosa (UFV), Viçosa-MG, Brasil; raphael.o.melo@ufv.br; herminia@ufv.br
}

\begin{abstract}
Boron (B) fertilizer application for tomato crop can be carried out by applying the nutrient to the soil or by spraying liquid solutions on leaves. The use of different fertilizers containing B can interfere in fertilization efficiency, since the performance of each product can be determined by its physicochemical properties. The aim of this study was to evaluate the application efficiency of two boron-based commercial foliar fertilizers applied at two time intervals and their possible effects on production components of Sweet Grape tomato. An experiment was conducted under commercial hydroponic system in split-split plot scheme that combined two doses of boron in the nutrient solution [sufficient $\left(25 \mu \mathrm{mol} \mathrm{L}{ }^{-1}\right)$ or insufficient $(6.25 \mu \mathrm{mol}$ $\left.\mathrm{L}^{-1}\right)$ ], two intervals between foliar sprays of B (seven or 14-day intervals) and two commercial foliar fertilizers [boric acid $\left(0.34 \mathrm{~g} \mathrm{~L}^{-1}\right)$ and sodium octaborate $\left.\left(0.36 \mathrm{~g} \mathrm{~L}^{-1}\right)\right]$. A positive effect of boron foliar fertilization was observed on the productivity or on fruit quality when a condition of B deficiency was noticed in plants, without significant difference in effects concerning the two B-source and the frequency of these applications.
\end{abstract}

Keywords: Solanum lycopersicum, micronutrient, leaf fertilization, hydropony.

\section{RESUMO}

Produção e qualidade do tomate Sweet Grape em resposta à fertilização foliar com boro

A adubação com boro (B) do tomateiro pode ser feita fornecendo-se o nutriente via solo ou por meio de pulverização de soluções direcionadas às folhas. $\mathrm{O}$ uso de distintas fontes de $\mathrm{B}$ nas soluções pulverizadas nas folhas pode interferir na eficiência dessa fertilização, pois o desempenho de cada produto pode ser determinado pelas suas propriedades físico-químicas. Dessa forma objetivou-se com este trabalho avaliar a eficiência da aplicação de dois fertilizantes foliares comerciais contendo boro, aplicados em duas frequências, e seus possíveis efeitos nos componentes de produção e qualidade do tomate Sweet Grape. Para isso, foi implementado um experimento em sistema hidropônico comercial em esquema de parcelas sub-subdivididas, em que foram fornecidas duas doses de boro na solução nutritiva: suficiente $\left(25 \mu \mathrm{mol} \mathrm{L} \mathrm{L}^{-1}\right)$ ou insuficiente $(6,25$ $\left.\mu \mathrm{mol} \mathrm{L} \mathrm{L}^{-1}\right)$, acompanhadas de pulverizações foliares com aplicação em intervalos de 7 ou 14 dias, utilizando-se os seguintes adubos foliares comerciais: ácido bórico $\left(0,34 \mathrm{~g} \mathrm{~L}^{-1}\right)$ e octaborato de sódio $\left(0,36 \mathrm{~g} \mathrm{~L}^{-1}\right)$. Os resultados evidenciaram que a fertilização foliar com B só foi efetiva para aumentar a produção, ou afetar os atributos de qualidade dos frutos quando foi imposta uma condição de deficiência de B nas plantas, não havendo distinção de efeitos com a aplicação das duas diferentes fontes de boro, assim como com as frequências de aplicação.

Palavras-chave: Solanum lycopersicum, micronutriente, adubação foliar, hidroponia.

\section{Received on January 24, 2019; accepted on August 26, 2019}

$\mathrm{T}_{\mathrm{b}}$ omato cultivar Sweet Grape has been standing out in the market as besides of its small size, sweet and characteristic flavor; it has high productivity (Preczenhak et al., 2009). This cultivar produces a large number of flowers per floral cluster (30 in average), being conducted commercially with two or more stems, which increase the number of flowers during reproductive phase (Heath, 2012). Flower set depends on the appropriate availability of water, nutrients and good phytossanitary conditions. Moreover, in order to ensure a good flower set, the air temperature should be from 10 to $32^{\circ} \mathrm{C}$ (Alvarenga, 2013).

Among the nutrients, boron (B) has great importance for flower set, stimulating pollen grain germination, and pollen tube growth (Lee et al., 2009). Boron is also a micronutrient that affects positively fruit quality, since, with calcium, provides resistance and stability to cell wall (Liebisch et al., 2009). Additionally, B plays an important role in other important biological processes in plant, such as metabolism and transport of carbohydrates and cell division (Taiz \& Zeiger, 2013).

Marschner (2012) reports that for most cultivated species, as for tomato plant, B is considered a phloem-immobile element. In certain environmental conditions, B deficiency in plants may occur, even being 
sufficient in the rhizosphere, due to a low redistribution of this element in phloem (Wimmer \& Eichert, 2013). Given the above, continuous supply of boron via xylem is necessary in order to meet the requirement for new forming organs such as fruits, flowers and meristematic zones (Marschner, 2012). Thus, B foliar applications are a viable alternative to supply the needs of deficient tomato plants (Gondim et al., 2014).

Fageria et al. (2009) state that nutrients, for which higher efficiency occurs when applied as foliar sprays, are the ones which are necessary for plants in low quantities, and that show restricted mobility in plant. Boron stands out in this context. The authors highlight that micronutrient supply through foliar fertilization has low cost due, among other reasons, to the fact that smaller quantities of product are required and they can be applied in admixture with most pesticides (Fernandez et al., 2015).

Foliar fertilization is a tool increasingly used for increasing crop productivity (Fernandez et al., 2015). However, little is known about situations in which foliar fertilizers can complement fertilization via roots, since controversy in the results obtained regarding the potential of this technology can be verified (Fageria et al., 2009).

The availability of commercial products for foliar fertilizations has been increasing in the last years, few controlled studies proving the efficiency of these products can be found, though. According to Fageria et al. (2009) and Fernandez et al. (2015), the nutrient source used in leaf application can interfere in the efficiency, and in the potential of this technology, since performance of each product can be determined by their own physicochemical properties.

The aim of this study was to evaluate the effect of spraying B sources, during reproductive cycle, on production and quality of Sweet Grape tomato cultivated under hydroponic system.

\section{MATERIAL AND METHODS}

The experiment was carried out from September to December, 2016, in the Departamento de Fitotecnia at Universidade Federal de Viçosa, Minas Gerais, Brazil $\left(20^{\circ} 45^{\circ e} 14\right.$ "S, $42^{\circ} 52^{\circ} 55^{\prime \prime} \mathrm{W}$; $650 \mathrm{~m}$ altitude), in a glasscovered greenhouse, with $2.4 \mathrm{~m}$ ceiling height and open lateral sides closed with an anti aphid mesh.

Seedlings of cultivar Sweet Grape were produced in a commercial nursery (Agro Mudas ${ }^{\circledR}$ ) located in the Municipality of Pará de Minas-MG. Sowing was performed in expanded polystyrene trays of 128 cells, filled with coconut fiber substrate. At 40 days after sowing, the seedlings were transplanted into 8-liter pots containing commercial coconut fiber substrate Golden Mix ${ }^{\circledR}$. Spacing was $0.5 \mathrm{~m} \times 1.0 \mathrm{~m}$ between plants and rows, respectively. Plants were conducted with two stems and staked using ribbons, afterwards they were pruned above the third leaf over the sixth flower cluster of each stem. Sprout thinning was constantly carried out in order to eliminate lateral sprouts.

The nutrient solution used was described by Fernandes et al. (2002) with some modifications: $8.0 ; 2.0 ; 4.0$; 2.0; 1.0 and $1.0 \mathrm{mmol} \mathrm{L}^{-1} \mathrm{~N}, \mathrm{P}, \mathrm{K}, \mathrm{Ca}$, $\mathrm{Mg}$ and $\mathrm{S}$ and $50.0 ; 20.07 .5 ; 4.0 ; 0.9$ and $0.7 \mu \mathrm{mol} \mathrm{L}^{-1} \mathrm{Fe}, \mathrm{B}, \mathrm{Mn}, \mathrm{Zn}, \mathrm{Cu}$ and $\mathrm{Mo}$ for vegetative phase, used from the first to the twentieth first day after transplant (DAT) and $12.0 ; 2.0 ; 6.0 ; 3.0 ; 1.5$ and $1.5 \mathrm{mmol} \mathrm{L}^{-1} \mathrm{~N}, \mathrm{P}, \mathrm{K}, \mathrm{Ca}, \mathrm{Mg}$ and $\mathrm{S}$ and $60.0 ; 10.0 ; 4.0 ; 1.3$ and $0.7 \mu \mathrm{mol} \mathrm{L}^{-1} \mathrm{Fe}$, $\mathrm{Mn}, \mathrm{Zn}, \mathrm{Cu}$ and Mo for reproductive phase (22 to 112 DAT). During this phase, half of the plants received 25 $\mu \mathrm{mol} \mathrm{L}-1 \mathrm{~B}$, according to Fernandes et al. (2002) for this crop and the other half received only $6.25 \mu \mathrm{mol} \mathrm{L}^{-1} \mathrm{~B}$ (reduction of $75 \%$ of the recommended dose).

The nutrient solution contained in the 60 -L reservoirs of each treatment, circulated through a $0.25 \mathrm{HP}$ motor pump set, which fed the irrigation lines. The irrigation system was activated daily at 6 a.m. 9 a.m., 11 a.m., 12 noon, 1 p.m., 2 p.m., 3 p.m. and 6 p.m. controlled by an electronic timer. The solution volume was $520 \mathrm{~mL}$ for each minute. From the first to the $40^{\circ}$ days after transplant (DAT) the pumps remained on for 2 minutes for each irrigation schedule; from $41^{\circ}$ to $80^{\circ}$ DAT for 3 minutes and from $81^{\circ}$ to $112^{\circ}$
DAT for 4 minutes. Nutrient solution drained from the pots returned to tanks by gravity through manifolds fixed below the benches, and then, the pumps recirculated this solution to the pots.

Solution $\mathrm{pH}$ was adjusted daily, keeping from 5.5 to 6.5 using $\mathrm{HCl}$ or $\mathrm{NaOH}$. Nutrients were resupplied, based on electrical conductivity reduction, admitting up to $30 \%$ depletion. Among these adds, solution volume of each tank was completed with water whenever it was necessary, admitting a maximum reduction of $40 \%$ of the initial volume.

The experiment was conducted in a split-split plot scheme with four replicates, in a randomized block design, considering as plots the boron doses into nutrient solution, sufficient $\left(25 \mu \mathrm{mol} \mathrm{L}^{-1}\right)$ or insufficient $\left(6.25 \mu \mathrm{mol} \mathrm{L}{ }^{-1}\right)$. In the subplots, boron foliar fertilizers were tested: boric acid, sodium octaborate and water as control treatment. In the sub-subplots there were allocated the frequencies of foliar fertilization, seven or 14 days.

The source of boric acid was the product under the tradename Boron 10 (Oxiquímica ${ }^{\circledR}$ ), showing the following physicochemical characteristics: B content: $17.5 \%$; density at $20^{\circ} \mathrm{C}: 1.3$ $\mathrm{g} \mathrm{cm}^{-3} ; \mathrm{pH}$ : 5.3; solubility in water: $100 \%$; physical nature: homogeneous suspension. The source of sodium octaborate was the product under the trade name of Boron Plus (Ecofol $\left.{ }^{\circledR}\right)$ : B content: $20.0 \%$; density at $20^{\circ}: 1.1 \mathrm{~g}$ $\mathrm{cm}^{-3} ; \mathrm{pH}: 7.0$; solubility in water: $100 \%$; physical nature: powder.

Foliar applications began from the beginning of flowering (22 DAT) and finished in the last week of the experimental period (112 DAT) totalizing 12 and six applications for the intervals of seven and 14 days, respectively. We have used 48 units, considering that each plant represented an experimental unit.

The quantities of foliar fertilizers applied to the plants were calculated according to the doses and volumes of solution recommended by the manufacturers for their respective products. In this way, each plant received a dose of $0.34 \mathrm{~g} \mathrm{~L}^{-1}$ and $0.36 \mathrm{~g} \mathrm{~L}^{-1} \mathrm{~B}$ for boric acid and sodium octaborate, respectively, and a fixed volume of 50 
$\mathrm{mL}$ of spraying mixture per plant in each application. Fertilizer applications were performed with the aid of a manual sprayer with a full cone nozzle. Plastic curtains were stretched between plants during spraying, in order to avoid drift of the sprayed solution to the neighbor plants.

Phytosanitary management of plants was performed according to practices recommended for tomato cultivation in a protected environment (Vida et al., 2004). During the experiment, the plants were sprayed with Thiamethoxam at $4 \mathrm{~g}$ for $20 \mathrm{~L}$, Acetamiprid at $5 \mathrm{~g}$ for $20 \mathrm{~L}$, Abamectina at $15 \mathrm{~mL}$ for $20 \mathrm{~L}$ and Teflubenzuron at $5 \mathrm{~mL}$ for $20 \mathrm{~L}$ to control insect pests and Tebuconazol at $20 \mathrm{~mL}$ for $20 \mathrm{~L}$ to control diseases. The number and frequency of applications followed the prescription of each used product.

Harvest was done weekly from 60 DAT, collecting only ripe fruits following standards described by Heath (2012) for the cultivar Sweet Grape. Afterwards, fruits were counted, weighed and classified into commercial and non-commercial according to standards for commercialization determined by Sakata Sudamerica ${ }^{\circledR}$ : Commercial fruits, weighing from 5 to $18 \mathrm{~g}$, without cracking, apical rot and pests or diseases. The fruits which did not show these characteristics were classified as non-commercial.

To evaluate fruit quality, twenty ripe commercial fruits of the third and fourth floral cluster of each plant were sampled to determine firmness, $\mathrm{pH}$, soluble solids content (SS) and titratable acidity (AT). Firmness was evaluated using five fruits, and determined with the aid of a bench-top penetrometer with a 4-mm diameter cone tip. A sample of $10-\mathrm{mL}$ of juice was extracted from fruits to determine SS content ( ${ }^{\circ}$ Brix) with a digital refractometer, and $\mathrm{pH}$ with a potentiometer. To determine AT, juice was diluted with distilled water in 1:20 ratio and titrated with $\mathrm{NaOH}$ solution $0.005 \mathrm{~mol} \mathrm{~L}^{-1}$ up to $\mathrm{pH} 8.2$.

To evaluate nutritional status of the plants, there was picked the fourth leaf downward the apex (index leaf) of each stem of each plant, when the first ripe fruits appeared, at 50 DAT. The harvested leaves were washed in distilled water, and dried in a drying oven with forced air circulation at $65^{\circ} \mathrm{C}$ until they reached constant mass. At 80 DAT, 6 fruits of the third and fourth flower cluster were sampled. The sampled fruits were washed in distilled water, cut, and put in aluminum trays and, then taken to a drying oven at $65^{\circ} \mathrm{C}$ in order to dry until they reach constant mass. The samples of fruits and leaves were ground using a Willey type mill. Then, dry digestion was done in muffle furnace at $550^{\circ} \mathrm{C}$. The $\mathrm{B}$ contents were determined colorimetrically in these extracts by the method of Azomethine H (Wolf, 1974).

The obtained data were submitted to analysis of variance using software R. Averages were compared using Tukey test at 5\% probability when $\mathrm{F}$ test showed interactions between the treatments (Table 1).

\section{RESULTS AND DISCUSSION}

Foliar fertilization increased productive indexes, and altered quality of Sweet Grape tomatoes, when B dose into nutrient solution was insufficient

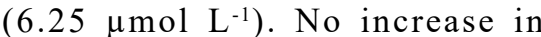
production and quality of fruits was observed when foliar fertilizers were applied to plants cultivated under adequate $\mathrm{B}$ dose in nutrient solution (25 $\left.\mu \mathrm{mol} \mathrm{L}{ }^{-1}\right)$. Results can be found in Table 1.

Foliar application, using two B sources under insufficient concentration of B in nutrient solution $\left(6.25 \mu \mathrm{mol} \mathrm{L}^{-1}\right)$, increased production indexes (TP and $\mathrm{CP})$ that reached the same mean values observed in plants which received the adequate $\mathrm{B}$ dose $\left(25 \mu \mathrm{mol} \mathrm{L} \mathrm{L}^{-1}\right)$ (Table 1). Similarly, Prado et al. (2013) observed that tomato plants, cultivar Raisa, subjected to omission of B in the

Table 1. Total fruit production (TP), commercial fruit production (CP), B concentration in leaves (BCL), B concentration in fruits (BCFR), soluble solids (SS) and ratio between soluble solids/titratable acidity (SS/TA) of tomato cv Sweet Grape grown in hydroponic system and subjected to doses of boron in the nutrient solution and foliar sprays with different fertilizers. Viçosa, UFV, 2016.

\begin{tabular}{|c|c|c|c|c|}
\hline \multirow[t]{3}{*}{ Fertilizer source } & \multicolumn{2}{|c|}{ TP $P^{1}$ (g/plant) } & \multicolumn{2}{|c|}{$\mathrm{CP}^{2}$ (g/plant) } \\
\hline & \multicolumn{4}{|c|}{ Boron doses in nutrient solution $\left(\mu \mathrm{mol} \mathrm{L}^{-1}\right)$} \\
\hline & 25 & 6.25 & 25 & 6.25 \\
\hline Boric acid & $3245 \mathrm{Aa}$ & $3199 \mathrm{Aa}$ & $2927 \mathrm{Aa}$ & $2817 \mathrm{Aa}$ \\
\hline Sodium octaborate & $3239 \mathrm{Aa}$ & $3174 \mathrm{Aa}$ & $2934 \mathrm{Aa}$ & $2797 \mathrm{Aa}$ \\
\hline \multirow[t]{3}{*}{ Water (control) } & $3185 \mathrm{Aa}$ & $2663 \mathrm{Bb}$ & $2806 \mathrm{Aa}$ & $2477 \mathrm{Bb}$ \\
\hline & \multicolumn{2}{|c|}{$\mathrm{BCL}^{3}$} & \multicolumn{2}{|c|}{$\mathrm{BCFR}^{4}$} \\
\hline & \multicolumn{4}{|c|}{$(\mathrm{mg} / \mathrm{kg})$} \\
\hline Boric acid & $160.2 \mathrm{Aa}$ & $132.9 \mathrm{Ab}$ & $27.0 \mathrm{Aa}$ & $19.5 \mathrm{Ab}$ \\
\hline Sodium octaborate & $150.6 \mathrm{Aa}$ & $126.8 \mathrm{Ab}$ & $27.4 \mathrm{Aa}$ & $18.5 \mathrm{Ab}$ \\
\hline \multirow[t]{2}{*}{ Water (control) } & $87.7 \mathrm{Ba}$ & $38.6 \mathrm{Bb}$ & $17.8 \mathrm{Ba}$ & $12.7 \mathrm{Bb}$ \\
\hline & \multicolumn{2}{|c|}{$\mathrm{SS}^{5}\left({ }^{\circ} \mathrm{Brix}\right)$} & \multicolumn{2}{|c|}{$\mathrm{SS} / \mathrm{TA}^{6}$} \\
\hline Boric acid & $7.5 \mathrm{Aa}$ & $7.8 \mathrm{Aa}$ & $14.8 \mathrm{Aa}$ & $14.9 \mathrm{Aa}$ \\
\hline Sodium octaborate & 7.9 Aa & 7.6 Aa & 15.1 Aa & $14.5 \mathrm{Aa}$ \\
\hline Water (control) & $7.7 \mathrm{Aa}$ & $8.7 \mathrm{Bb}$ & $14.8 \mathrm{Aa}$ & $16.1 \mathrm{Bb}$ \\
\hline
\end{tabular}

${ }^{1}$ Total production obtained by the sum of the weight of commercial and non-commercial fruits of plants cultivated until $112 \mathrm{DAT} ;{ }^{2} \mathrm{Commercial}$ production, obtained by the weight of commercial fruits of plants cultivated until 112 DAT; ${ }^{3}$ Boron concentration in leaves collected at $50 \mathrm{DAT} ;{ }^{4}$ Boron concentration in fruits collected at $80 \mathrm{DAT} ;{ }^{5}$ Soluble solids of fruits collected at $80 \mathrm{DAT} ;{ }^{6}$ Soluble and titratable acidity ratio of fruits collected at $80 \mathrm{DAT}$. Averages followed by same letters, uppercase for effects of B source in foliar fertilization, and lowercase for boron doses in nutrient solution, do not differ among them by Tukey test, at $5 \%$ probability. 
nutrient solution presented a production equivalent to that of plants receiving an adequate dose of $\mathrm{B}$ in the solution when sprayed with boric acid $\left(0.17 \mathrm{~g} \mathrm{~L}^{-1}\right)$.

Reductions in total (TP) and commercial $(\mathrm{CP})$ productions of plants which received $\mathrm{B}$-deficient nutrient solution and did not receive the nutrient by foliar fertilization (Table 1) might have occurred due to a greater floral abortion and/or fewer flowers produced, since the average weight of fruits was not affected by treatments. Such plants showed $\mathrm{B}$ concentration in leaves (BCL) lower than the critical level (Table 1), which is 50 to $70 \mathrm{mg} \mathrm{kg}^{-1}$ according to Malavolta et al. (1997), which explains the decrease in the production.

Such results highlight that B foliar fertilizations are not necessary on tomatoes cultivar Sweet Grape, fed with B-sufficient nutrient solution $(25 \mu \mathrm{mol}$ $\left.\mathrm{L}^{-1}\right)$, since no increase in production and quality of fruits in this condition was observed. However, we observed an increase in B concentrations in leaves and fruits of plants which were sprayed in relation to plants which were not sprayed. The concentrations observed, nevertheless, are above the critical level for the crop (50 to $70 \mathrm{mg} \mathrm{kg}^{-1}$ ) according to Malavolta et al. (1997), but below the toxicity zone $(209 \mathrm{mg}$ $\mathrm{kg}^{-1}$ ), according to Gunes et al. (1999) (Table 1). Nevertheless, it is important highlight that the high concentration of boron in the leaves of plants that were sprayed could be promoted by the $B$ retained in the leaf surface or in the cuticles better than by excessive concentration of $\mathrm{B}$ in the leaf cells.

The results of this study showed that different B sources applied via foliar (boric acid and sodium octaborate) did not show any differences between its efficiencies in increasing production and quality of fruits (Table 1). Unlike in cotton cultivated in a greenhouse, for which the sources boric acid and sodium borate resulted in differences in $B$ foliar concentration, whereas for soy the foliar concentration of $\mathrm{B}$ did not alter in response to the foliar sprays (Guertal et al., 1996).

The most commonly used source of boron in soil or foliar fertilizers is boric acid $\left(\mathrm{H}_{3} \mathrm{BO}_{3}\right)$ (Lemiska et al., 2014), and a plenty of studies on efficiency of $\mathrm{H}_{3} \mathrm{BO}_{3}$ application to tomato plants can be found (Roosta \& Hamidpour, 2011; Prado et al., 2013; Gondim et al., 2014). However, no study on sodium octaborate efficiency in foliar sprays on tomato plants was found. Nevertheless, some studies report positive effect of this salt for other crops such as sunflower (Martin et al., 2014) mustard, wheat and potato (Sarkar et al., 2007).

Intervals between boron foliar applications (seven and 14 days) did not influence the production, quality of fruits and B concentration in leaves and fruits (Table 2). These results showed that foliar fertilizer application every 14

Table 2. Total fruit production (TP), commercial fruit production (CP), B concentration in leaves (BCL), B concentration in fruits (BCFR), soluble solids (SS) and ratio between soluble solids/titratable acidity (SS/TA) of tomato cv Sweet Grape grown in hydroponic system subjected to different doses of boron in the nutrient solution and foliar sprays with different fertilizers applied at intervals of seven and 14 days from flowering until ripening. Viçosa, UFV, 2016.

\begin{tabular}{|c|c|c|c|c|c|c|}
\hline \multirow{2}{*}{ Spray intervals } & $\mathbf{T P}^{1}$ & $\mathbf{C P}^{2}$ & $\mathbf{B C L}^{3}$ & BCFR $^{4}$ & \multirow{2}{*}{$\begin{array}{c}\text { SS }^{5} \\
\left({ }^{\circ} \text { Brix }\right)\end{array}$} & \multirow{2}{*}{$\mathbf{S S} / \mathbf{A T}^{6}$} \\
\hline & \multicolumn{2}{|c|}{ (g/plant) } & \multicolumn{2}{|c|}{ (mg/kg) } & & \\
\hline 7 days & $3112.7 \mathrm{a}$ & $2744.2 \mathrm{a}$ & $125.0 \mathrm{a}$ & $23.8 \mathrm{a}$ & 7.7 & 15.4 \\
\hline 14 days & $3168.2 \mathrm{a}$ & $2847.6 \mathrm{a}$ & $106.4 \mathrm{a}$ & $19.9 \mathrm{a}$ & 7.5 & 15.0 \\
\hline CV (\%) & 13.80 & 6.90 & 13.8 & 11.6 & 8.3 & 5.4 \\
\hline
\end{tabular}

${ }^{1}$ Total production, obtained by the sum of the weight of commercial and non-commercial fruits of plants cultivated until $112 \mathrm{DAT} ;{ }^{2}$ Commercial production, obtained by the weight of commercial fruits of plants cultivated until $112 \mathrm{DAT} ;{ }^{3}$ Boron content in leaves collected at $50 \mathrm{DAT} ;{ }^{4}$ Boron level in tomato of salad group fruits collected at $80 \mathrm{DAT} ;{ }^{5}$ Soluble solids of fruits collected at $80 \mathrm{DAT} ;{ }^{6}$ Solids soluble and titratable acidity ratio of fruits collected at 80 DAT. Averages followed by same letters in each column do not differ by the F test, at $5 \%$ probability. days, increased production and kept fruit quality when a B deficiency in nutrient solution was verified, and no need to apply the products weekly was noticed; considering that a weekly application would be considered an excess. Gondim et al. (2014) carried out an experiment with tomato belonging to salad group, without boron in the nutrient solution and observed that three applications of $\mathrm{H}_{3} \mathrm{BO}_{3}$ at $0.34 \mathrm{~g} \mathrm{~L}^{-1}$ during the cycle would be enough to meet plant requirements on $\mathrm{B}$.

The lowest number of fruits produced in plants which received B-deficient nutrient solution $\left(6.25 \mu \mathrm{mol} \mathrm{L}^{-1}\right)$, and did not receive foliar fertilization (Table 1), resulted in concentration effect over the sugar contents in fruits produced in such conditions. In fact, an increase in soluble solids content (SS) can be verified, which consequently resulted in a higher ratio between titratable acidity and soluble solids of fruits (SS/ AT) (Table 1). As this variable is related to fruit flavor, an appropriate nutrition management using boron may reach a good relationship between productivity and quality. Lemiska et al (2014) also observed reduction in strawberry production followed by increase in sugar concentration in the fruits when leaves and soil received no boron application.

Foliar fertilizer application was not enough to increase fruit firmness, even showing a significant increase in $B$ concentrations in fruits (BCFR) when plants were sprayed with both $B$ sources (Table 1). Although the participation of $\mathrm{B}$ in the formation and extension of cell walls is well known, according to Liebisch et al. (2009), Ca (which was always available in this experiment) plays a major role when compared to $B$ in the formation of pectins which make up the cell walls of fruits.

The results obtained in this study corroborate results of Sá et al. (2014), study which concluded that foliar sprays of $\mathrm{H}_{3} \mathrm{BO}_{3}$ at $0.3 \%$ in reproductive phase, associated with application of B increasing doses via soil, does not increase firmness of the pulp of apple cultivars Imperial Gala and Fuji Suprema. By the other hand, our results are different from the ones obtained by Lemiska et al. (2014), which observed 
greater firmness of strawberry fruits when foliar applications of $\mathrm{H}_{3} \mathrm{BO}_{3}$ were done.

We concluded that in tomato cv. Sweet Grape cultivated under hydroponic system, the reduction of $\mathrm{B}$ dose into nutrient solution results in a reduction of fruit production and an increase in soluble solids content. In such conditions, B foliar applications every 14 days, applied from beginning of flowering until ripening, reverse the effect of low concentration of $B$ in the nutrient solution. In this condition the foliar fertilizers, boric acid and sodium octaborate, are equivalent in maintaining Sweet Grape tomato production.

\section{ACKNOWLEDGEMENTS}

To $\mathrm{CNPq}$ for granting the master scholarship, and CAPES for the doctorate scholarship for the first author. To Sakata Sudamerica ${ }^{\circledR}$ for allowing the development of this study on cultivar Sweet Grape.

\section{REFERENCES}

ALVARENGA, MAR. 2013. Tomate: Produção em campo, em casa-de-vegetação e em hidroponia. Lavras: Editora UFLA. 455p.

FAGERIA, NK; BARBOSA FILHO, MP; MOREIRA, A; GUIMARÃES, CM. 2009. Foliar fertilization of crop plants. Journal of Plant Nutrition 32: 1044-1064.

FERNANDES, AA; MARTINEZ, HEP; FONTES, PCR. 2002. Produtividade, qualidade dos frutos e estado nutricional do tomateiro tipo longa vida conduzido com um cacho, em cultivo hidropônico, em função das fontes de nutrientes. Horticultura Brasileira 20: 564-570.

FERNÁNDEZ, V; SOTIROPOULOS, T; BROWN, P. 2015. Adubação foliar: fundamentos cientificos e técnicas de campo. São Paulo: Abisolo. 150p.

GONDIM, ARO; PRADO, RM; FILHO, ABC; ALVES, AU; CORREIA, MAR. 2014. Boron foliar application in nutrition and yield of beet and tomato. Journal of Plant Nutrition 38: 1573-1579.

GUERTAL, EA; ABAYE, AO; LIPPERT, BM; MINER, GS; GASCHO, GJ. 1996. Sources of boron for foliar fertilization of cotton and soybean. Communications in Soil Science and Plant Analysis 27: 2815-2828.

GUNES, A; ALPASLAN, M; CIKILI, Y; OZCAN, H. 1999. Effect of zinc on the alleviation of boron toxicity in tomato. Journal of Plant Nutrition 22: 1061-1068.

HEATH, DW. 2012. US Patent 8,097,792. Available at >https://www.google.com/ patents/US8,097,792<; accessed April 18, 2017.

LEE, SH; KIM, WS; HAN, TH. 2009. Effects of post-harvest foliar boron and calcium applications on subsequent season's pollen germination and pollen tube growth of pear (Pyrus pyrifolia). Scienta Horticultare 122: 77-82.

LEMISKA, A; PAULETTI, V; CUQUEL, FL; ZAWADNEAK, MAC. 2014. Produção e qualidade da fruta do morangueiro sob influência da aplicação de boro. Ciência Rural 44: 622-628.

LIEBISCH, F; MAX, JFJ; HEINE G; HORST, WJ. 2009. Blossom-end rot and fruit cracking of tomato grown in net-covered greenhouse in Central Thailand can partly be corrected by calcium and boron sprays. Journal of Plant Nutrition and Soil Science 172: 140-150.

MALAVOLTA, E; VITTI, GC; OLIVEIRA, SA. 1997. Avaliação do estado nutricional das plantas: princípios e aplicações. Piracicaba: POTAFOS. 319p.

MARSCHNER, P. 2012. Mineral nutrition of higher plants. 3. ed. London: Academic
Press. 651p.

MARTIN, TN; PAVINATO, PS; MENEZES, LFG; SANTI, AL; BERTONCELLI, P; ORTIZ, S; LUDWIG, RL. 2014.Utilização de cálcio e boro na produção de grãos e silagem de girassol. Semina: Ciências Agrárias 35: 2699-2710.

PRADO, RM; GONDIM, ARO; CECÍLIO FILHO, AB; ALVES, AU; CORREIA, MAR; ABREU-JUNIOR, CH. 2013. Boron foliar aplication in nutrition and yield of beet and tomato. Communications in Soil Science and Plant Analysis 44: 1435-1443.

PRECZENHAK, AP; RESENDE, JTV; CHAGAS, RR; SILVA, PR; SCHWARZ, K; MORALES, RGF. 2009. Caracterização agronômica de genótipos de minitomate. Horticultura Brasileira 32: 348-356.

ROOSTA, HR; HAMIDPOUR, M. 2011. Effects of foliar application of some macro- and micro-nutrients on tomato plants in aquaponic and hydroponic systems. Scientia Horticultare 129: 396-402.

SÁ, AA; ERNANI, PR; NAVA, G; AMARANTE, CVT; PEREIRA, AJ. 2014. Influência de formas de aplicação de boro na qualidade e no rendimento de maçãs (Malus domestica). Revista Brasileira de Fruticultura 36: $487-$ 494.

SARKAR, D; MANDAL, B; KUNDU, MC. 2007. Increasing use efficiency of boron fertilizers by rescheduling the time and methods of application for crops in India. Plant Soil 301: 77-85.

VIDA, JB; ZAMBOLIM, L; TESSMANN, DJ; BRANDÃO FILHO, JUT; VERZIGNASSI, JR; CAIXETA, MP. 2004. Manejo de doenças de plantas em cultivo protegido. Fitopatologia Brasileira, 29: 355-372.

TAIZ, L; ZEIGER, E. 2013. Fisiologia vegetal. Porto Alegre: Artmed. 954p.

WIMMER, MA; EICHERT, T. 2013. Mechanism for boron deficiency-mediated changes in plant water relations. Plant Science 203: 25-32.

WOLF, B. 1974. Improvents in the azomethine-H method for determination of boron. Communications in Soil Science and Plant Analysis 5:39-44. 